\title{
From 5-Hydroxymethylfurfural (HMF) to Polymer Precursors: Catalyst Screening Studies on the Conversion of 1,2,6-hexanetriol to 1,6-hexanediol
}

\author{
Teddy Buntara $\cdot$ Sebastien Noel $\cdot$ Pim Huat Phua $\cdot$ \\ Ignacio Melián-Cabrera $\cdot$ Johannes G. de Vries • \\ Hero J. Heeres
}

Published online: 3 July 2012

(C) The Author(s) 2012. This article is published with open access at Springerlink.com

\begin{abstract}
1,6-hexanediol (1) is an important polymer precursor for the polyester industry. In this paper, exploratory catalyst screening studies on the synthesis of $\mathbf{1}$ from 1,2,6-hexanetriol (2) are described via two different routes. The latter is available by a two-step procedure from 5-hydroxymethylfurfural (HMF, 3), a promising bio-based platform chemical. In the first approach, the direct catalytic hydrodeoxygenation of $\mathbf{2}$ to $\mathbf{1}$ with heterogeneous catalysts and molecular hydrogen was explored. Best results were obtained using a $\mathrm{Rh}-\mathrm{ReO}_{\mathrm{x}} / \mathrm{SiO}_{2}$ catalyst in water $\left(180{ }^{\circ} \mathrm{C}\right.$, 80 bar $\mathrm{H}_{2}, 20 \mathrm{~h}$ reaction time), leading to full conversion of 2 and $73 \%$ selectivity to 1 , the main byproduct being 1,5-hexanediol (4). In a second approach, 2 was first converted to tetrahydropyran-2-methanol (2-THPM, 5) in quantitative yield using triflic acid as catalyst $\left(125^{\circ} \mathrm{C}\right.$, $30 \mathrm{~min}$ ). Various catalysts were explored for the subsequent ring opening/hydrodeoxygenation of 5 to $\mathbf{1}$ using a hydrogenation protocol and the best results were obtained with a $\mathrm{Rh}-\mathrm{ReO}_{\mathrm{x}} / \mathrm{SiO}_{2}$ catalyst, viz. $96 \%$ selectivity to $\mathbf{1}$ at $26 \%$ conversion $\left(120^{\circ} \mathrm{C}, 80\right.$ bar $\left.\mathrm{H}_{2}, 20 \mathrm{~h}\right)$.
\end{abstract}

T. Buntara $\cdot$ S. Noel $\cdot$ P. H. Phua $\cdot$ I. Melián-Cabrera .

H. J. Heeres ( $\square)$

Department of Chemical Engineering, University of Groningen,

Nijenborgh 4, 9747 AG Groningen, The Netherlands

e-mail: H.J.Heeres@ rug.nl

J. G. de Vries

Stratingh Institute of Chemistry, University of Groningen,

Nijenborgh 4, 9747 AG Groningen, The Netherlands

J. G. de Vries $(\square)$

DSM Innovative Synthesis BV, P.O. Box 18, 6160 MD Geleen,

The Netherlands

e-mail: Hans-JG.Vries-de@dsm.com
Keywords Renewable chemicals - Hydrogenation · Rhodium · Rhenium - Support - Hydrodeoxygenation

\section{Introduction}

1,6-hexanediol (1) is an important chemical for use in the production of high performance polyesters, polyurethane resins, and adhesives [1]. In 2000, the worldwide production volume of $\mathbf{1}$ was about 33,000 ton/year [2]. The major route to 1 involves the hydrogenation of adipic acid or its esters (e.g. dimethyl adipate) using heterogeneous catalysts based on carbon supported Ru-Pt-Sn [3-5], Cu-Cr-Ba oxide [6], Snmodified Raney Ru [7], various copper-based catalysts [8, 9], $\mathrm{CuO} / \mathrm{ZnO} / \mathrm{Al}_{2} \mathrm{O}_{3}[10-14]$, and $\mathrm{RuSn} / \mathrm{Al}_{2} \mathrm{O}_{3}[15,16]$ (Eq. 1).

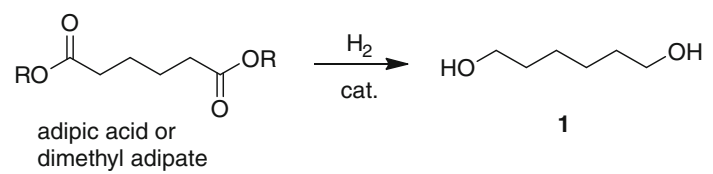

Our interest in this field concerns the synthesis of green 1,6-hexanediol from renewable resources. We have recently shown the proof of principle for the reaction of hydroxymethylfurfural HMF (3) to 1 via THF-dimethanol (THFDM) and 1,2,6-hexanetriol (2) as the intermediates (Eq. 2) [17].

HMF is considered to be a promising bio-based platform chemical and is regarded as a "sleeping giant" in the field of intermediate chemicals from renewable resources [18]. It is accessible by acid-catalyzed dehydration of the C6-sugars (e.g. D-glucose, D-fructose, and D-mannose) present in lignocellulosic biomass. HMF derivatives like dimethylfuran [19-21] and its ethers such as methoxymethylfurfural and ethoxymethylfurfural [22] have potential as fuel (additives), whereas 2,5-furandicarboxylic acid (FDCA) [23-31], and 


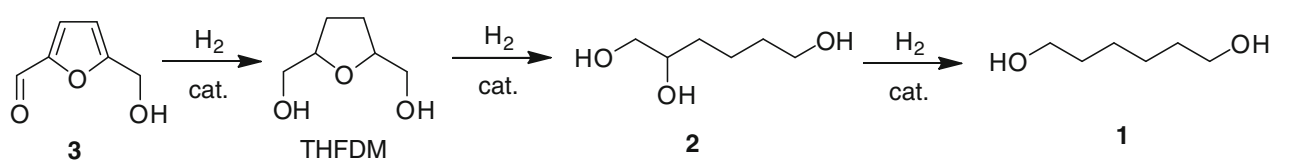

tetrahydrofuran-dimethanol (THFDM) may serve as building blocks in advanced polymers [32-38].

Here, we report catalytic screening studies on the synthesis of the diol $\mathbf{1}$ from triol $\mathbf{2}$. The reaction involves the selective removal of a secondary alcohol in the presence of two primary alcohols. A well-known approach involves catalytic hydrodeoxygenation using heterogeneous catalysts and, in most cases, molecular hydrogen. Examples for structurally related alcohols like 1,2-propanediol (6), 1,2butanediol (7), 1,2-pentanediol (8), and 1,2-hexanediol (9) are provided in Table 1.

Bimetallic catalysts based on Rh-Re, Ir-Re, and Pt-W have shown to be very promising catalyst and selectivities between 73 and $90 \%$ are reported. In some cases soluble acids (e.g. sulfuric acid) were added to improve catalytic conversions. There are also reports [46-52] on the use of homogeneous ruthenium catalysts in combination with triflic acid (HOTf) and sulfolane as the solvent for the selective hydrodeoxygenation of a secondary alcohol in the presence of a primary alcohol. For example, Schlaf et al. [51] reported the production of 1-propanol from 6 using $\left[\left\{\mathrm{Cp} * \mathrm{Ru}(\mathrm{CO})_{2}\right\}_{2}(\mu-\mathrm{H})\right]^{+} \mathrm{OTf}^{-}\left(52\right.$ bar $\left._{2}, 110{ }^{\circ} \mathrm{C}, 30 \mathrm{~h}\right)$ and obtained $92 \%$ conversion with $54 \%$ selectivity to 1-propanol. Better results were obtained [46] using [cis$\left.\mathrm{Ru}\left(6,6^{\prime}-\mathrm{Cl}_{2} \text {-bipy }\right)_{2}\left(\mathrm{OH}_{2}\right)_{2}\right]\left(\mathrm{CF}_{3} \mathrm{SO}_{3}\right)_{2}\left(48\right.$ bar $\mathrm{H}_{2}, 125^{\circ} \mathrm{C}$, $48 \mathrm{~h}$ ), giving $63 \%$ yield of 1-propanol.

While preparing this manuscript, Dumesic et al. [44] reported hydrodeoxygenation reactions of various diols and triols using bimetallic $\mathrm{Rh}-\mathrm{ReO}_{\mathrm{x}}$ catalysts on carbon supports. When using $\mathbf{2}$ as the substrate, $\mathbf{1}$ was obtained in $99.9 \%$ at $8 \%$ conversion $\left(120{ }^{\circ} \mathrm{C}, 34 \mathrm{bar}, 4 \mathrm{~h}\right)$. Prolonged reaction times $(14 \mathrm{~h})$ resulted in improved conversions (59\%), though, the selectivity to 1 was reduced considerably (62\%).

In this paper, a catalyst screening study on the conversion of 1,2,6-hexanetriol to 1,6 hexanediol using a hydrodeoxygenation approach is reported. Emphasis is on the use of bimetallic $\mathrm{Rh}-\mathrm{Re}$ complexes on various supports, though monometallic catalysts have been tested as well, and the results will be compared.

\section{Materials and Methods}

\subsection{Materials}

$1(97 \%)$ and tetrahydropyran-2-methanol 5 (98 \%) were purchased from Aldrich. 2 ( $>97 \%)$ was purchased from Acros. 1-propanol (>99\%) was purchased from Merck Chemicals. Sulfolane (99\%) was purchased from Aldrich. Triflic acid (99\%), para-toluenesulfonic acid monohydrate $(>98.5 \%)$, aluminum chloride hexahydrate $(>99 \%)$, copper triflate $(98 \%)$, and potassium carbonate $(99 \%)$ were purchased from Aldrich.

Copper chromite catalysts were kindly supplied by BASF (Cu-1985P) and Süd-Chemie (T-4419), as well as purchased from Aldrich (product number: 209325). Copper zinc PRICAT CZ/A P and PRICAT CZ/B P catalysts were kindly supplied by Johnson Matthey. Copper zinc T-2130 was kindly supplied by Süd-Chemie. $\mathrm{Ru} / \mathrm{C}(5 \% \mathrm{w} / \mathrm{w}), \mathrm{Ru} / \mathrm{Al}_{2} \mathrm{O}_{3}$ $\left(5 \%\right.$ w/w), Pt/C (5\% w/w), Rh/C (5\% w/w), Rh/ $/ \mathrm{Al}_{2} \mathrm{O}_{3}$ (5\% w/w), Pd/C (5\% w/w), and $\mathrm{Pd} / \mathrm{Al}_{2} \mathrm{O}_{3}(5 \% \mathrm{w} / \mathrm{w})$ were purchased from Aldrich. $\mathrm{RuCl}_{3}$ was purchased from Strem.
Table 1 Overview of catalytic reactions involving selective removal of secondary alcohol group in the presence of primary alcohol groups

${ }^{\text {a }}$ With Amberlyst-15; ${ }^{\text {b}}$ With sulfuric acid; ${ }^{\mathrm{c}}$ No solvent

\begin{tabular}{|c|c|c|c|c|c|c|c|}
\hline Substrate & Catalyst & $\mathrm{T}\left({ }^{\circ} \mathrm{C}\right)$ & $\mathrm{P} \mathrm{H}_{2}$ (bar) & $\mathrm{t}(\mathrm{h})$ & $\%$-conv. & $\%$ selectivity & References \\
\hline 6 & $\mathrm{Pt} / \mathrm{WO}_{3} / \mathrm{ZrO}_{2}$ & 140 & 40 & 24 & 91 & 90 & [39] \\
\hline 6 & $\mathrm{Rh} / \mathrm{SiO}_{2}^{\mathrm{a}}$ & 120 & 80 & 10 & 18 & 57 & [40] \\
\hline 6 & $\mathrm{Rh} / \mathrm{SiO}_{2}$ & 120 & 80 & 10 & 10 & 67 & [40] \\
\hline 6 & $\mathrm{Rh}-\mathrm{ReO}_{\mathrm{x}} / \mathrm{SiO}_{2}$ & 120 & 80 & 24 & 87 & 74 & [41] \\
\hline 6 & $\mathrm{Ir}-\mathrm{ReO}_{\mathrm{x}} / \mathrm{SiO}_{2}^{\mathrm{b}}$ & 120 & 80 & 24 & 72 & 85 & [42] \\
\hline 6 & $\mathrm{CeO}_{2}^{\mathrm{c}}$ & 375 & - & n.a. & 11 & 23 & [43] \\
\hline 7 & $\mathrm{Rh}-\mathrm{ReO}_{\mathrm{x}} / \mathrm{C}$ & 120 & 34 & 4 & 15 & 78 & [44] \\
\hline 7 & $\mathrm{CeO}_{2}^{\mathrm{c}}$ & 375 & - & n.a. & 16 & 17 & {$[43]$} \\
\hline 8 & $\mathrm{Rh}-\mathrm{ReO}_{\mathrm{x}} / \mathrm{C}$ & 120 & 34 & 4 & 9 & 88 & [44] \\
\hline 9 & $\mathrm{Rh}-\mathrm{ReO}_{\mathrm{x}} / \mathrm{C}$ & 120 & 34 & 4 & 12 & 80 & [44] \\
\hline 9 & $\mathrm{Rh}-\mathrm{ReO}_{\mathrm{x}} / \mathrm{C}$ & 100 & 80 & 24 & 52 & 78 & {$[45]$} \\
\hline 9 & $\mathrm{Rh}-\mathrm{ReO}_{\mathrm{x}} / \mathrm{SiO}_{2}$ & 100 & 80 & 24 & 76 & 73 & {$[45]$} \\
\hline
\end{tabular}


$\mathrm{Ru} / \mathrm{TiO}_{2}(5 \%$ w/w) was purchased from Degussa and a supported nickel catalyst G-69B was kindly supplied by Süd-Chemie. $\quad \mathrm{RhCl}_{3} \cdot \mathrm{nH}_{2} \mathrm{O}$ ( $\left.\mathrm{Rh} 38-40 \%\right)$, ammonium perrhenate $(>99 \%)$, ammonium molybdate tetrahydrate $\left(\mathrm{MoO}_{3} 81-83 \%\right)$ were purchased from Aldrich while tinchloride dihydrate ( $>98 \%$ ) was purchased from Riedel-de Haën. Ammonium tungsten oxide ( $>99.99 \%$ ) was purchased from Alfa Aesar. CARiACT G-6 3 micron silica was donated by Fuji Silysia. $\mathrm{TiO}_{2}$ (product number: 14021), $\mathrm{SiO}_{2}-\mathrm{Al}_{2} \mathrm{O}_{3}$ (grade 135), and activated carbon (product number: 484164) were purchased from Aldrich. $\gamma-\mathrm{Al}_{2} \mathrm{O}_{3}$ (product number: 044658) was purchased from Alfa Aesar. Hydrogen gas (>99.9999 \%) was purchased from Hoek Loos.

\subsection{Methods}

\subsubsection{General procedure for the preparation of the bimetallic $\mathrm{Rh}-\mathrm{ReO} \mathrm{O}_{x}$ catalysts}

All catalyst preparations were carried out in air. An aqueous solution of $\mathrm{RhCl}_{3} \cdot \mathrm{nH}_{2} \mathrm{O}(176 \mathrm{mg}, 0.8 \mathrm{mmol})$ in water $(5 \mathrm{~mL})$ was added to silica (2 g, Fuji CARiACT G-6 3 micron; BET surface area $529 \mathrm{~m}^{2} \mathrm{~g}^{-1}$ and pore volume $0.617 \mathrm{~cm}^{3} \mathrm{~g}^{-1}$ ) and stirred for $2 \mathrm{~h}$ at room temperature. After drying at $383 \mathrm{~K}$ for 13-14 h, the solid was added to an aqueous solution of ammonium perrhenate $(113 \mathrm{mg}, 0.4 \mathrm{mmol})$ in water $(5 \mathrm{~mL})$ and stirred for $2 \mathrm{~h}$, followed by drying at $383 \mathrm{~K}$ for $13-14 \mathrm{~h}$. Calcination in air at $773 \mathrm{~K}$ for $3 \mathrm{~h}$ gave the catalyst containing $4 \mathrm{wt} \%$ of $\mathrm{Rh}$ and a $\mathrm{Re} / \mathrm{Rh}$ molar ratio of 0.5 .

The same procedure was used for the preparation of other Rh-based bimetallic catalysts, except for $\mathrm{Rh}-\mathrm{ReO}_{\mathrm{x}} / \mathrm{C}$, where the calcination step was omitted. Ammonium molybdate tetrahydrate $(131 \mathrm{mg}, 0.1 \mathrm{mmol})$, ammonium tungsten oxide $(30 \mathrm{mg}, 0.1 \mathrm{mmol})$, and tinchloride dihydrate (94 $\mathrm{mg}, 0.4 \mathrm{mmol}$ ) were used for preparing the $\mathrm{Rh}-\mathrm{MoO}_{\mathrm{x}} / \mathrm{SiO}_{2}, \mathrm{Rh}-\mathrm{WO}_{\mathrm{x}} / \mathrm{SiO}_{2}$, and $\mathrm{Rh}-\mathrm{SnO}_{\mathrm{x}} / \mathrm{SiO}_{2}$ catalysts.

\subsubsection{Reaction Procedure for the Catalyst Screening Study of 2 to 1 in 1-propanol}

2 (100 mg, $0.75 \mathrm{mmol})$, catalyst (10 mg), 1-propanol $(2 \mathrm{~mL})$ and a Teflon stirring bar were added to an $8 \mathrm{~mL}$ glass vial capped with a septum, which was punctured with a short needle. The vial was placed in a stainless-steel autoclave, the autoclave was closed and stirring was started at $1,000 \mathrm{rpm}$. After three times pressurizing with first nitrogen and then hydrogen, the autoclave was pressurized with hydrogen to 10 bar and the temperature was raised to $180{ }^{\circ} \mathrm{C}$. After $1 \mathrm{~h}$, the pressure was raised to 80 bar and the reaction was continued for $3 \mathrm{~h}$. Then, the autoclave was allowed to cool to ambient temperature and the pressure was released. The reactor content was filtered to remove the catalyst and the filtrate was subjected to GC analysis.

\subsubsection{Reaction of 2 to 1 Using $\mathrm{CuCr}$ Catalysts at an Elevated Temperature}

2 (500 mg, $4 \mathrm{mmol}$ ) dissolved in 1-propanol (30 mL) and a $\mathrm{CuCr}$ catalyst $(100 \mathrm{mg}$ ) were added to a $100 \mathrm{~mL}$ stainless steel autoclave (Parr). The reactor was flushed three times with nitrogen and subsequently with hydrogen. After flushing, the reactor was pressurized to $100 \mathrm{bar}$, and the reaction mixture was stirred $(1,000 \mathrm{rpm})$ and heated to $260{ }^{\circ} \mathrm{C}$ for $6 \mathrm{~h}$. Then, the autoclave was allowed to cool to ambient temperature and the pressure was released. Product mixtures were filtered to remove the catalyst and the filtrate was subjected to GC analysis.

\subsubsection{General Reaction Procedure for the Reaction of $\mathbf{2}$ to 1 in Water}

$2(100 \mathrm{mg}, \quad 0.75 \mathrm{mmol})$, the $\mathrm{Rh}-\mathrm{ReO}{ }_{\mathrm{x}} / \mathrm{SiO}_{2}$ catalyst (10 $\mathrm{mg})$, water $(2 \mathrm{~mL})$ and a Teflon stirring bar were added to an $8 \mathrm{~mL}$ glass vial capped with a septum, which was pierced by a short needle. The vial was placed in a stainless-steel autoclave, the autoclave was closed and stirring was started at $1,000 \mathrm{rpm}$. After three times pressurizing with first nitrogen and then hydrogen, the autoclave was pressurized with hydrogen to $10 \mathrm{bar}$ and the temperature was raised to $180{ }^{\circ} \mathrm{C}$. After $1 \mathrm{~h}$, the pressure was raised to 80 bar and the reaction was continued for $3 \mathrm{~h}$. Then, the autoclave was allowed to cool to ambient temperature and the pressure was released. The reactor content was filtered to remove the catalyst and the filtrate was subjected to GC analysis.

\subsubsection{Cyclization of 2 to 5}

In a $100 \mathrm{~mL}$ three-neck round bottom flask, 2 (3.354 g, $25 \mathrm{mmol})$ was dissolved in sulfolane $(25 \mathrm{~mL})$. Then, triflic acid (13.3 $\mu \mathrm{L}, 0.15 \mathrm{mmol}$ ) was added and the reaction mixture was heated to $125{ }^{\circ} \mathrm{C}$ for $30 \mathrm{~min}$. The reaction mixture was cooled and analysed using GC-FID, GC-MS and ${ }^{1} \mathrm{H}$ - and ${ }^{13} \mathrm{C}-\mathrm{NMR}$.

\subsubsection{General Procedure for the Reaction of $\mathbf{5}$ to $\mathbf{1}$ in Water}

The procedure described here is for the $\mathrm{Rh}-\mathrm{ReO} / \mathrm{SiO}_{2}$ catalyst. The same procedure was used for all other catalysts. 5 (100 mg, $0.9 \mathrm{mmol})$, the $\mathrm{Rh}-\mathrm{ReO}_{\mathrm{x}} / \mathrm{SiO}_{2}$ catalyst (10 mg), water ( $2 \mathrm{~mL})$ and a Teflon stirring bar were added to a glass vial and the hydrogenation was performed as described above for the hydrogenolysis of $\mathbf{2}$, except that the content was stirred for $3.5 \mathrm{~h}$ at 80 bar instead of $3 \mathrm{~h}$. Product mixtures were filtered to remove the catalyst and the filtrate was subjected to GC analysis. 


\subsubsection{Product Analyses}

Gas chromatography using a CP-WAX57CB column (25 m length, $0.2 \mathrm{~mm}$ internal diameter, and $0.25 \mu \mathrm{m}$ film thickness) and a flame ionization detector (GC-FID) was used for product identification and quantification. The injector and the detector temperature were set at $250{ }^{\circ} \mathrm{C}$. The oven temperature was kept at $40{ }^{\circ} \mathrm{C}$ for $5 \mathrm{~min}$ then heated up to $180{ }^{\circ} \mathrm{C}$ with a heating rate of $5{ }^{\circ} \mathrm{C} / \mathrm{min}$ and to $230{ }^{\circ} \mathrm{C}$ with a heating rate of $10{ }^{\circ} \mathrm{C} / \mathrm{min}$ and kept at kieselguhr (promoted with zirconium). Most of the catalysts were not active at the prevailing reaction condition, the only exceptions being $\mathrm{Ru} / \mathrm{C}$ and the bimetallic $\mathrm{Rh}-\mathrm{ReO}_{\mathrm{x}}$ on silica. Activity though, was very low and the conversion of $\mathbf{2}$ was less than $10 \%$ (5\% for $\mathrm{Rh}-\mathrm{ReO}_{\mathrm{x}} / \mathrm{SiO}_{2}$ and $8 \%$ for $\mathrm{Ru} / \mathrm{C}$ ) with a selectivity to 1 of $57 \%$ for $\mathrm{Rh}-\mathrm{ReO}_{\mathrm{x}} / \mathrm{SiO}_{2}$ and $56 \%$ for $\mathrm{Ru} / \mathrm{C}$. The byproduct for the reaction with $\mathrm{Rh}-\mathrm{ReO}_{\mathrm{x}} / \mathrm{SiO}_{2}$ catalyst was the undesired 1,5-hexanediol 4 (Eq. 3), byproducts for the reaction with $\mathrm{Ru} / \mathrm{C}$ were not identified. It is clear that both $\mathrm{Ru} /$ $\mathrm{C}$ and $\mathrm{Rh}-\mathrm{ReO}_{\mathrm{x}} / \mathrm{SiO}_{2}$ showed similar performance.

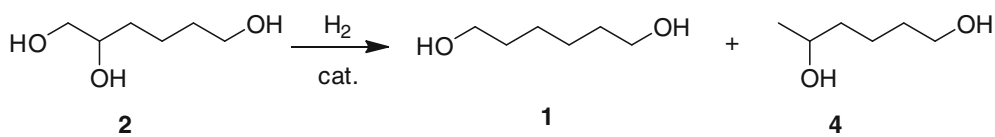

this temperature for $15 \mathrm{~min}$. A split ratio of 50 was used. Helium was used as the carrier gas with a flow rate of $1.1 \mathrm{~mL} / \mathrm{min}$. Toluene was used as an internal standard for the GC analysis.

GC-MS analyses was performed on a Hewlett-Packard 5890 gas chromatograph equipped with a quadrupole Hewlett-Packard 6890 MSD selective detector and a $30-\mathrm{m} \times 0.25-\mathrm{mm}$ internal diameter $\times 0.25-\mu \mathrm{m}$-film sol-gel capillary column. The injector temperature was set at $250{ }^{\circ} \mathrm{C}$. The oven temperature was kept at $40{ }^{\circ} \mathrm{C}$ for $5 \mathrm{~min}$, then increased to $250{ }^{\circ} \mathrm{C}$ at a heating rate of $3{ }^{\circ} \mathrm{C} / \mathrm{min}$, and then held at $250{ }^{\circ} \mathrm{C}$ for $10 \mathrm{~min}$.

\section{Results and Discussion}

\subsection{One-step Conversion of $\mathbf{2}$ to $\mathbf{1}$}

The screening studies revealed that $\mathrm{CuCr}$ catalysts were not active under the prevailing reaction conditions. This is remarkable as Utne and co-workers reported the use of copper chromite catalyst for the direct conversion of THFDM to $\mathbf{1}$, most likely also involving $\mathbf{2}$ as an intermediate. However, the reaction conditions used by Utne (300 ${ }^{\circ} \mathrm{C}$ and 380 bar) to obtain a 40-50\% yield of 1 were far more severe than used here [53]. Thus, additional experiments were performed with $\mathrm{CuCr}$ (BASF) at elevated temperatures and pressures $\left(260{ }^{\circ} \mathrm{C}, 100 \mathrm{bar}, 6 \mathrm{~h}, 1\right.$-propanol) using 2 as the substrate. At these conditions, the catalyst is indeed active and $93 \%$ conversion of 2 was achieved. The selectivity to 1, though, was relatively low (46\%), giving a yield of $43 \%$, in the same range as observed by Utne under more severe conditions. Byproducts were the diol 4 (25\%), tetrahydropyran-2-methanol (5, $11 \%)$, 1-hexanol (10, $10 \%)$, and 1,5-pentanediol (11, $8 \%)$, (Eq. 4).
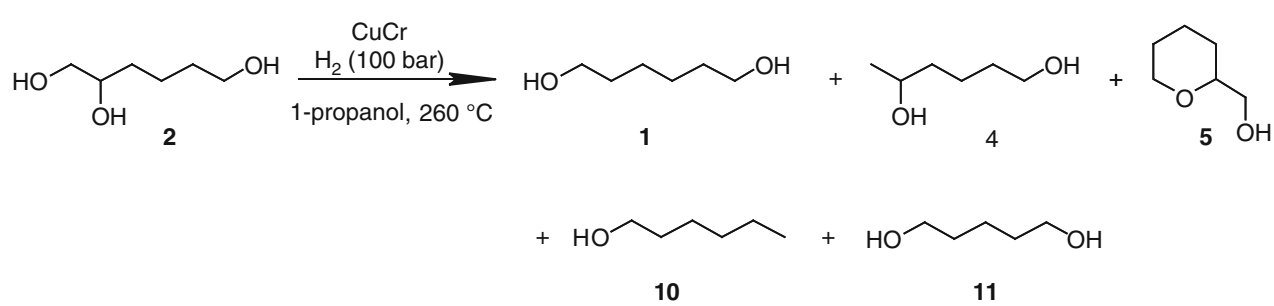

\subsubsection{Exploratory Catalyst Screening Studies}

\subsubsection{Detailed Studies Using Bimetallic Rh-Re Catalysts}

A wide range of catalysts were screened for the catalytic hydrodeoxygenation of $\mathbf{2}$ to $\mathbf{1}$ in 1-propanol as the solvent ( $180{ }^{\circ} \mathrm{C}, 3 \mathrm{~h}, 80$ bar) including $\mathrm{CuCr}$ (three types), $\mathrm{CuZn}$ (three types), $\mathrm{Ru}$-based catalysts $\left(\mathrm{Ru} / \mathrm{C}, \mathrm{Ru} / \mathrm{TiO}_{2}, \mathrm{Ru} / \mathrm{Al}_{2} \mathrm{O}_{3}\right.$ ), Rh-based catalysts $\left(\mathrm{Rh}-\mathrm{ReO}_{\mathrm{x}} / \mathrm{SiO}_{2}, \mathrm{Rh} / \mathrm{C}, \mathrm{Rh} / \mathrm{Al}_{2} \mathrm{O}_{3}, \mathrm{Rh} /\right.$ $\left.\mathrm{SiO}_{2}\right), \mathrm{Pd}$-based catalysts $\left(\mathrm{Pd} / \mathrm{Al}_{2} \mathrm{O}_{3}, \mathrm{Pd} / \mathrm{C}\right), \mathrm{Pt} / \mathrm{C}$, and $\mathrm{Ni} /$

Further investigations aimed to increase the yield of 1,6-hexanediol were performed using bimetallic $\mathrm{Rh}-\mathrm{Re}$ catalysts on various supports in water as solvent (Table 2).

The conversion and selectivity to $\mathbf{1}$ were considerably higher in water than in 1-propanol, the solvent in the screening study. These differences in catalytic performances may be 
Table 2 Overview of the reaction of $\mathbf{2}$ to $\mathbf{1}$ using Rh-Re catalysts ${ }^{\mathrm{a}}$

\begin{tabular}{lrccc}
\hline Cat. system & \%-conv. & $\begin{array}{l}\% \text {-sel. } \\
\text { to } \mathbf{1}\end{array}$ & $\begin{array}{l}\% \text {-sel. } \\
\text { to } \mathbf{4}\end{array}$ & $\begin{array}{l}\% \text {-sel. } \\
\text { to others }\end{array}$ \\
\hline $\mathrm{Rh}-\mathrm{ReO}_{\mathrm{x}} / \mathrm{SiO}_{2}^{\mathrm{b}}$ & 5 & 57 & 28 & 15 \\
$\mathrm{Rh}-\mathrm{ReO}_{\mathrm{x}} / \mathrm{SiO}_{2}$ & 17 & 73 & 27 & 0 \\
$\mathrm{Rh}-\mathrm{ReO}_{\mathrm{x}} / \mathrm{SiO}_{2}+\gamma-\mathrm{Al}_{2} \mathrm{O}_{3}$ & 22 & 69 & 24 & 7 \\
$\mathrm{Rh}-\mathrm{ReO}_{\mathrm{x}} / \mathrm{SiO}_{2}-\mathrm{Al}_{2} \mathrm{O}_{3}$ & 7 & 66 & 19 & 15 \\
$\mathrm{Rh}-\mathrm{ReO}_{\mathrm{x}} / \mathrm{SiO}_{2}-\mathrm{Al}_{2} \mathrm{O}_{3}^{\mathrm{c}}$ & 20 & 76 & 18 & 6 \\
$\mathrm{Rh}-\mathrm{ReO}_{\mathrm{x}} / \gamma-\mathrm{Al}_{2} \mathrm{O}_{3}$ & 3 & 38 & 22 & 40 \\
$\mathrm{Rh}-\mathrm{ReO}_{\mathrm{x}} / \mathrm{SiO}_{2}+\mathrm{K}_{2} \mathrm{CO}_{3}$ & 1 & 0 & 0 & 100 \\
$\mathrm{~K}_{2} \mathrm{CO}_{3}$ & 1 & 0 & 0 & 100
\end{tabular}

${ }^{\mathrm{a}} T=180{ }^{\circ} \mathrm{C}, \mathrm{P}_{1}=10$ bar, $\mathrm{t}_{1}=1 \mathrm{~h}, \mathrm{P}_{2}=80$ bar, $\mathrm{t}_{2}=3 \mathrm{~h}$, catalyst $=10 \mathrm{wt} \%$, solvent $=$ water; ${ }^{\mathrm{b}}$ solvent $=1$-propanol; ${ }^{\mathrm{c}} \mathrm{t}_{2}=20 \mathrm{~h}$

due to competitive adsorption of the solvent (1-propanol) and the substrate on the $\mathrm{ReO}_{\mathrm{x}}$ clusters. Tomishige et al. [54] proposed a mechanism for the reaction of THF-alcohol to 1,5 pentanediol using $\mathrm{Rh}-\mathrm{Re}$ catalysts. It involves coordination of the $\mathrm{OH}$ group of the substrate to Re and subsequent hydrogenolysis of the $\mathrm{C}-\mathrm{O}$ bond by the neighboring $\mathrm{Rh}$ centre. Thus, it is possible that water is bound more weakly to Re than 1-propanol, leading to enhanced reaction rates.

The possible positive effects of enhanced acidity on catalyst performance, as observed in the literature (Table 1), was probed by investigating the use of more acidic supports, either by using bimetallic Rh-Re catalyst on $\gamma$-alumina and mixed silica-alumina supports or the addition of $\gamma$-alumina to a bimetallic $\mathrm{Rh}-\mathrm{Re}$ catalyst on silica. The use of a Rh-Re catalyst on alumina for alcohol deoxygenation studies has to the best of our knowledge not been reported before.

Reaction using $\mathrm{Rh}-\mathrm{Re}$ on silica in combination with alumina (without $\mathrm{Rh}-\mathrm{Re}$ ), led to slightly higher conversions than for the reaction in the absence of alumina ( $22 \mathrm{vs.}$ $17 \%$ ), though the selectivity to $\mathbf{1}$ was slightly reduced (69\% vs. $73 \%$ ). Thus, it seems that catalyst activity is positively affected by the addition of alumina.
The use of a bimetallic Rh-Re catalyst on $\gamma$-alumina led to low catalyst activities ( $3 \%$ conversion vs. $17 \%$ for silica), in line with the results for the mixed silica-alumina catalyst. Thus, the use of alumina instead of silica or partial substitution of silica by alumina has a negative effect on catalyst performance.

Experiments with the standard $\mathrm{Rh}-\mathrm{Re}$ catalyst on silica in the presence of $\mathrm{K}_{2} \mathrm{CO}_{3}$ gave a negligible conversion at standard conditions, an indication that bases have a negative effect on the reaction rates. Similar observations were reported by Dumesic and co-workers [44] for the conversion of 5 using $\mathrm{Rh}-\mathrm{ReO}_{\mathrm{x}}$ catalysts on carbon in the presence of $0.1 \mathrm{M} \mathrm{NaOH}\left(120{ }^{\circ} \mathrm{C}, 34\right.$ bar $\left.\mathrm{H}_{2}, 4 \mathrm{~h}\right)$.

The effects of the process conditions (temperature, reaction time) on the hydrogenation of $\mathbf{2}$ were investigated using the Rh-Re on silica catalyst (Table 3). Temperature has a profound effect on catalyst activity and conversions of $\mathbf{2}$ increased from $9 \%$ to near quantitative conversion at $180{ }^{\circ} \mathrm{C}$ for reaction times of $20-24 \mathrm{~h}$. The almost constant selectivity to 1 at the different conversion levels (67-73\%) is remarkable. It suggests that the activation energy for the desired reaction to $\mathbf{1}$ is rather similar to that of the undesired reaction to 4 .

\subsection{Two-step Synthetic Approach Via \\ Tetrahydropyran-2-methanol}

Experiments on the conversion of $\mathbf{2}$ using $\mathrm{CuCr}$ catalysts in 1-propanol at elevated pressures and temperatures (vide supra) resulted in the formation of tetrahydropyran-2methanol 5 as a side product (Eq. 4). This compound may be considered as an intermediate in the reaction sequence, as it is formed by an intramolecular etherification of $\mathbf{2}$, and a ring opening reaction could either lead to diol $\mathbf{1}$ or $\mathbf{9}$ (Eq. 5). This observation triggered us to perform additional catalytic hydrogenation experiments using $\mathbf{5}$ as the starting material.

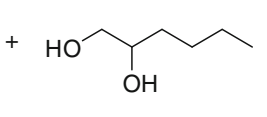

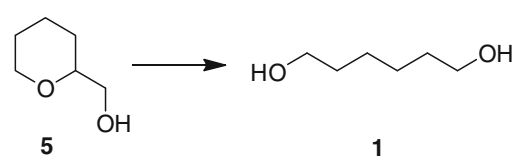

9

Reactions at standard conditions with a Rh-Re catalyst on a mixed silica-alumina support led to considerably lower conversions compared to the silica only catalyst (7 vs. $17 \%$ ). Further prolongation of the reaction time to $20 \mathrm{~h}$ led to $20 \%$ conversion with $76 \%$ selectivity to 1 . The selectivity at this conversion level is similar to that of the silica only catalyst. Thus, the use of mixed alumina-silica supports leads to a considerable reduction in catalyst activity, though the selectivity is comparable with that of silica at similar conversion levels. Apparently, silica is essential for high catalyst activity.
Synthetic methodology for the synthesis of $\mathbf{5}$ has been reported; examples are the oxidative cyclization reaction of 5-hexen-1-ol [55-57] using TS-1 $\left(60^{\circ} \mathrm{C}, 6 \mathrm{~h}\right)[55,56]$ or a PNIPAAm- $-\mathrm{PW}_{12} \mathrm{O}_{40}{ }^{3-}$ complex $\left(60{ }^{\circ} \mathrm{C}, 6 \mathrm{~h}\right)$ [57] to give $90 \%$ and $70 \%$ yield of $\mathbf{5}$, respectively. The synthesis of $\mathbf{5}$ from 2 [58] using $\mathrm{BuSnCl}_{3}$ as the catalyst $\left(230{ }^{\circ} \mathrm{C}, 3 \mathrm{~h}\right)$ has also been explored and $\mathbf{5}$ was obtained in $60 \%$ yield.

An improved synthetic procedure was developed by us involving the acid catalysed ring-closure of 2 using triflic acid in sulfolane at $125{ }^{\circ} \mathrm{C}$. After $30 \mathrm{~min}$, conversion was 
Table 3 Effect of process conditions on reaction of $\mathbf{2}$ to $\mathbf{1}$ using a $\mathrm{Rh}-\mathrm{ReO}_{\mathrm{x}} / \mathrm{SiO}_{2}$ catalyst $^{\mathrm{a}}$

\begin{tabular}{lccll}
\hline $\mathrm{T}\left({ }^{\circ} \mathrm{C}\right)$ & $\mathrm{t}_{2}(\mathrm{~h})$ & \%-conv. & \%-sel. to $\mathbf{1}$ & \%-sel. to $\mathbf{4}$ \\
\hline 120 & 24 & 9 & 67 & 19 \\
150 & 20 & 19 & 71 & 24 \\
180 & 3 & 17 & 73 & 27 \\
180 & 20 & 100 & 73 & 28 \\
\hline
\end{tabular}

${ }^{\mathrm{a}} \mathrm{P}_{1}=10$ bar, $\mathrm{t}_{1}=1 \mathrm{~h}, \quad \mathrm{P}_{2}=80$ bar, catalyst $=10 \quad \mathrm{wt} \%$, solvent $=$ water

quantitative and $\mathbf{5}$ was the sole product (GC and GC-MS), indicating that it is a very viable alternative for the synthetic methodology using $n$-butyltin trichloride.

A wide range of catalysts was screened for the catalytic hydrogenolysis reaction of pyran $\mathbf{5}$ to $\mathbf{1}$ using hydrogen gas $\left(180{ }^{\circ} \mathrm{C}, 80 \mathrm{bar}, 3.5 \mathrm{~h}\right.$, water as solvent). Ru-based catalysts $\left(\mathrm{Ru} / \mathrm{C}, \mathrm{Ru} / \mathrm{Al}_{2} \mathrm{O}_{3}\right)$, Pd-based catalysts $\left(\mathrm{Pd} / \mathrm{C}, \mathrm{Pd} / \mathrm{Al}_{2} \mathrm{O}_{3}\right)$, $\mathrm{Cu}$-based catalysts $(\mathrm{CuCr}, \mathrm{CuZn}), \mathrm{Rh}$-based catalysts $(\mathrm{Rh} /$ $\mathrm{C}, \mathrm{Rh} / \mathrm{SiO}_{2}, \mathrm{Rh} / \mathrm{Al}_{2} \mathrm{O}_{3}$ ), Pt/C, and Ni/kieselguhr (promoted with zirconium) were not active at the prevailing reaction conditions. More promising results were obtained with bimetallic Rh-based catalysts on various supports (Table 4).

Four catalysts $\left(\mathrm{Rh}-\mathrm{ReO}_{\mathrm{x}} / \mathrm{SiO}_{2}, \mathrm{Rh}-\mathrm{ReO}_{\mathrm{x}} / \mathrm{TiO}{ }_{2}, \mathrm{Rh}-\right.$ $\left.\mathrm{ReO}{ }_{\mathrm{x}} / \mathrm{SiO}_{2}-\mathrm{Al}_{2} \mathrm{O}_{3}, \mathrm{Rh}-\mathrm{MoO}_{\mathrm{x}} / \mathrm{SiO}_{2}\right)$ gave up to $5-12 \%$ conversion with $100 \%$ selectivity to $\mathbf{1}$. The activity is a function of the support type and best results were obtained with titania. Surprisingly, the $\mathrm{Rh}-\mathrm{ReO}_{\mathrm{x}}$ on carbon catalyst is inactive, an observation not in line with literature data [44, 45]. Tomishige [45] reported $36 \%$ conversion with $97 \%$ selectivity to $1\left(100{ }^{\circ} \mathrm{C}, 80 \mathrm{bar}, 24 \mathrm{~h}\right)$ whilst Dumesic [44] obtained $27 \%$ conversion with $97 \%$ selectivity to $\mathbf{1}$ $\left(120{ }^{\circ} \mathrm{C}, 34 \mathrm{bar}, 4 \mathrm{~h}\right)$ using carbon supported catalysts. A possible explanation for these differences in catalytic performance is the use of a different catalyst preparation protocol. We did not perform a calcination step after catalyst synthesis to avoid partial destruction of the $\mathrm{C}$ support.

Replacement of $\mathrm{Re}$ in the bimetallic Rh-Re catalysts with other metals only led to an active catalyst in case of Mo. W and Sn promoted Rh-catalysts were not active.

Further improvements in catalytic performance were explored by variation of the Rh content of the catalyst at a fixed $\mathrm{Rh}-\mathrm{Re}$ ratio and the results are provided in Table 5. Higher Rh contents (6.5 wt \%) led to higher conversions but the selectivity to $\mathbf{1}$ decreased from 100 to $71 \%$. Also a reaction using this catalyst was performed with a higher catalyst intake ( $20 \mathrm{wt} \%)$ on substrate. Essential quantitative conversion was obtained ( $96 \%$ ), however the selectivity to $\mathbf{1}$ was only $55 \%$, the main byproduct being 1,2-hexanediol (9).

The effect of reaction conditions and particularly reaction time and temperature on catalyst performance of the $\mathrm{Rh}-\mathrm{Re} /$ silica catalyst was determined (Table 6). A low conversion, though with $100 \%$ selectivity to $\mathbf{1}$ was
Table 4 Results for catalyst screening study on the conversion of pyran 5 to diol $\mathbf{1}^{\text {a }}$

\begin{tabular}{lcc}
\hline Catalyst & \%-conv. & \%-sel. to 1 \\
\hline $\mathrm{Rh}-\mathrm{ReO}_{\mathrm{x}} / \mathrm{SiO}_{2}$ & 8 & 100 \\
$\mathrm{Rh}-\mathrm{ReO}_{\mathrm{x}} / \mathrm{TiO}_{2}$ & 12 & 100 \\
$\mathrm{Rh}-\mathrm{ReO}_{\mathrm{x}} / \mathrm{Al}_{2} \mathrm{O}_{3}$ & 0 & 0 \\
$\mathrm{Rh}-\mathrm{ReO}_{\mathrm{x}} / \mathrm{C}$ & 0 & 0 \\
$\mathrm{Rh}-\mathrm{ReO}_{\mathrm{x}} / \mathrm{SiO}_{2}-\mathrm{Al}_{2} \mathrm{O}_{3}$ & 5 & 100 \\
$\mathrm{Rh}-\mathrm{MoO}_{\mathrm{x}} / \mathrm{SiO}_{2}^{\mathrm{b}}$ & 9 & 100 \\
$\mathrm{Rh}-\mathrm{WO}_{\mathrm{x}} / \mathrm{SiO}_{2}^{\mathrm{c}}$ & 0 & 0 \\
$\mathrm{Rh}-\mathrm{SnO}_{\mathrm{x}} / \mathrm{SiO}_{2}$ & 0 & 0
\end{tabular}

${ }^{\mathrm{a}} \mathrm{T}=180{ }^{\circ} \mathrm{C}, \mathrm{P}_{1}=10$ bar, $\mathrm{t}_{1}=1 \mathrm{~h}, \mathrm{P}_{2}=80$ bar, $\mathrm{t}_{2}=3.5 \mathrm{~h}$, catalyst $=10 \mathrm{wt} \%$, water; ${ }^{\mathrm{b}}$ Mo to $\mathrm{Rh}$ molar ratio of $0.91 ;{ }^{\mathrm{c}} \mathrm{W}$ to $\mathrm{Rh}$ molar ratio of 0.13

Table 5 Conversion of pyran 5 to diol 1 using $\mathrm{Rh}-\mathrm{ReO}_{\mathrm{x}} / \mathrm{SiO}_{2}$ catalysts with various $\mathrm{Rh}$ contents and catalyst intakes

\begin{tabular}{lccc}
\hline Conditions & \%-conv. & \%-sel. to 1 & \%-sel. to 9 \\
\hline 4 wt\% Rh, 10 wt\% cat. & 8 & 100 & 0 \\
6.5 wt\% Rh, 10 wt\% cat. & 62 & 71 & 0 \\
6.5 wt\% Rh, 20 wt\% cat. & 96 & 55 & 35 \\
\hline
\end{tabular}

Table 6 Reaction of 5 to 1 using $\mathrm{Rh}-\mathrm{ReO}_{\mathrm{x}} / \mathrm{SiO}_{2}$ at different reaction conditions $^{\mathrm{a}}$

\begin{tabular}{llcc}
\hline $\mathrm{T}\left({ }^{\circ} \mathrm{C}\right)$ & $\mathrm{t}_{2}(\mathrm{~h})$ & $\%$-conv. & $\%$-sel. to $\mathbf{1}$ \\
\hline 180 & 3.5 & 62 & 71 \\
120 & 3.5 & 7 & 100 \\
120 & 20 & 26 & 96 \\
180 & 20 & 86 & 46 \\
\hline
\end{tabular}

a $\mathrm{P}_{1}=10 \mathrm{bar}, \mathrm{t}_{1}=1 \mathrm{~h}, \quad \mathrm{P}_{2}=80 \mathrm{bar}, \quad$ catalyst $=10 \mathrm{wt} \%$, solvent $=$ water

obtained at $120{ }^{\circ} \mathrm{C}$. Prolonged reaction times $(20 \mathrm{~h})$ at this temperature gave $26 \%$ conversion with $96 \%$ selectivity to 1. At elevated temperatures $\left(180^{\circ} \mathrm{C}\right)$ and $20 \mathrm{~h}$ reaction time, $86 \%$ conversion was obtained, though the selectivity to 1 dropped to $46 \%$. Thus, the most promising result was obtained at $120{ }^{\circ} \mathrm{C}$ and $20 \mathrm{~h}$ reaction time leading to a high selectivity to $1(96 \%)$ at a reasonable conversion (26\%).

\section{Conclusions}

The catalytic synthesis of 1,6-hexanediol from 1,2,6-hexanetriol using a hydrodeoxygenation approach with heterogeneous catalysts has been explored. Various catalysts have been tested and $\mathrm{Rh}-\mathrm{ReO}_{\mathrm{x}} / \mathrm{SiO}_{2}$ catalysts were found to be the best. Two approaches were explored, a one pot approach and a two-step approach using tetrahydropyran-2methanol $\mathbf{5}$ as the intermediate, see Eq. 6 for details. 


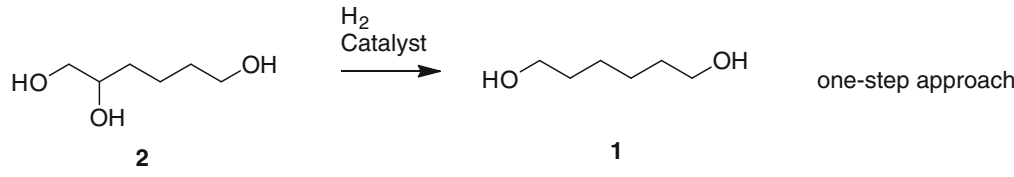

2

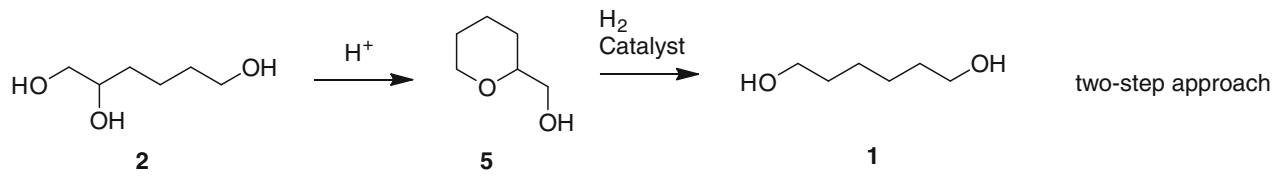

The one-step approach gave a very promising maximum yield of $\mathbf{1}$ of $73 \%$ at full conversion of $\mathbf{2}$. The first step in the two step approach was achieved in essentially quantitative yields. For the second step, the ring opening of $\mathbf{5}$ to diol 1, the Rh-Re catalyst showed excellent selectivity (96\%), though at a relatively low conversion level (26\%). Thus when aiming for an overall high selectivity, as preferred for bulk-chemical processes with elaborate recycle streams, the two step approach seems preferred.

Acknowledgments We would like to thank ACTS-ASPECT for providing a grant to perform this research (ASPECT Project 053.62.017), and Rudy Parton, Rob Meier (DSM), Peter Witte, Peter Berben (BASF), Annemarie Beers (Norit), Jean Paul Lange (Shell), and Bart Zwijnenburg (Johnson Matthey) for stimulating discussions and supply of catalysts.

Open Access This article is distributed under the terms of the Creative Commons Attribution License which permits any use, distribution, and reproduction in any medium, provided the original author(s) and the source are credited.

\section{References:}

1. Figueiredo FCA, Jordão E, Carvalho WA (2008) Appl Catal A $351: 259$

2. Weissermel K, Arpe HJ (2003) Components for polyamides. In: Industrial Organic Chemistry, Wiley-VCH, Weinheim

3. Hara Y, Endo K (1998) Jpn. Kokai Tokkyo Koho 10306047

4. Kayo A, Nakamura H (2000) Jpn. Kokai Tokkyo Koho 20003 27606

5. Hara Y, Endo K, Takahashi H (2001). Jpn. Kokai Tokkyo Koho 2001009277

6. Guyer A, Bieler A, Sommaruga M (1955) Helv Chim Acta 38:976

7. Ishimura Y, Hirayama H, Nozawa T, Monzen H (1997) Jpn. Kokai Tokkyo Koho 09059188

8. Pinkos R, Heimann J, Polka HM, Urtel H, Windecker G (2008) WO2008012229, to BASF AG

9. Pinkos R, Breuninger D, Tebben GD (2010) WO2010115798, to BASF AG

10. Yuan P, Liu Z, Hu T, Sun H, Liu S (2010) Reac Kinet Mech Cat 100:427
11. Lin P et al (2005) Faming Zhuanli Shenqing Gongkai Shuomingshu 1565729

12. Cheng G, Shi J, Zhang Y, Huang J, Shi M, Li M (2006) Jingxi Huagong Zhongjianti 36:67

13. Cheng $G$ et al (2008) Faming Zhuanli Shenqing Gongkai Shuomingshu 101113128

14. Cheng G et al (2008) Faming Zhuanli Shenqing Gongkai Shuomingshu 101265158

15. Santos SM, Silva AM, Jordão E, Fraga MA (2004) Catal Commun 5:377

16. Silva AM, Santos OAA, Morales MA, Baggio-Saitovitch EM, Jordão E, Fraga MA (2006) J Mol Catal A-Chem 253:62

17. Buntara T, Noel S, Phua PH, Cabrera IM, de Vries JG, Heeres HJ (2011) Angew Chem Int Ed 50:7083

18. Bicker M, Hirth J, Vogel H (2003) Green Chem 5:280

19. Román-Leshkov Y, Barrett CJ, Liu ZY, Dumesic JA (2007) Nature 447:982

20. Chidambaram M, Bell AT (2010) Green Chem 12:1253

21. Thananatthanachon T, Rauchfuss TB (2010) Angew Chem Int Ed 49:6616

22. Gruter GJM, Dautzenberg F (2007) European Patent 1834951, to Furanix Tecnologies BV

23. Ribeiro ML, Schuchardt U (2003) Catal Commun $4: 83$

24. Partenheimer W, Grushin VV (2001) Adv Synth Catal 343:102

25. Miura T, Kakinuma H, Kawano T, Matsuhisa H (2007) US20070232815, to Canon Kabushiki Kaisha

26. Davis SE, Houk LR, Tamargo EC, Datye AK, Davis RJ (2011) Catal Today 160:55

27. Pasini T, Piccinini M, Blosi M, Bonelli R, Albonetti S, Dimitratos N, Lopez-Sanches JA, Sankar M, He Q, Kiely CJ, Hutchings GJ, Cavanai F (2011) Green Chem 13:2091

28. Gupta NK, Nishimura S, Takagaki A, Ebitani K (2011) Green Chem 13:824

29. Lilga MA, Hallen RT, Gray M (2010) Top Catal 53:1264

30. Gorbanev YY, Klitgaard SK, Woodley JM, Christensen $\mathrm{CH}$, Riisager A (2009) ChemSusChem 2:672

31. Casanova O, Iborra S, Corma A (2009) ChemSusChem 2:1138

32. Haworth WN, Jones WGM, Wiggins LF (1945) J Chem Soc 1

33. Utne T, Garber JD, Jones RE (1963) US Patent 3083236, to Merck \& Co, Inc.

34. Hales RA (1962) US patent 3040062, to Atlas Chemical Industries, Inc.

35. Schiavo V, Descotes G, Mentech J (1991) Bull Soc Chim Fr 128:704

36. Lilga MA, Hallen RT, Werpy TA, White JF, Holladay JE, Frye JG Jr, Zacher AH (2007) US20070287845, to Batelle Memorial Institute

37. Sanborn AJ, Bloom PD (2006) US20060128843, to Archer Daniels Midland 
38. Connolly TJ et al (2010) Org Proc Res Dev 14:459

39. Qin LZ, Song MJ, Chen CL (2010) Green Chem 12:1466

40. Furikado I, Miyazawa T, Koso S, Shimao A, Kunimori K, Tomishige K (2007) Green Chem 9:582

41. Amada Y, Koso S, Nakagawa Y, Tomishige K (2010) ChemSusChem 3:728

42. Nakagawa Y, Shinmi Y, Koso S, Tomishige K (2010) J Catal 272:191

43. Sato S, Takahashi R, Sodesawa T, Honda N (2004) J Mol Catal A-Chem 221:177

44. Chia M, Pagán-Torres YJ, Hibbitts D, Tan Q, Pham HN, Datye AK, Neurock M, Davis RJ, Dumesic JA (2011) J Am Chem Soc 133:12675

45. Chen K, Koso S, Kubota T, Nakagawa Y, Tomishige K (2010) ChemCatChem 2:547

46. Xie Z, Schlaf M (2005) J Mol Catal A-Chem 229:151

47. Thibault ME, DiMondo DV, Jennings M, Abdelnur PV, Eberlin MN, Schlaf M (2011) Green Chem 13:357

48. Ghosh P, Fagan PJ, Marshall WJ, Hauptman E, Bullock RM (2009) Inorg Chem 48:6490
49. Taher D, Thibault ME, DiMondo D, Jennings M, Schlaf M (2009) Chem Eur J 15:10132

50. Dykeman RR, Luska KL, Thibault ME, Jones MD, Schlaf M, Khanfar M, Taylor NJ, Britten JF, Harrington L (2007) J Mol Cata. A-Chem 277:233

51. Schlaf M, Ghosh P, Fagan PJ, Hauptman E, Bullock RM (2009) Adv Synth Catal 351:789

52. Schlaf M, Ghosh P, Fagan PJ, Hauptman E, Bullock RM (2001) Angew Chem Int Ed 40:3887

53. Utne T, Jones RE, Garber JD (1962) US Patent 3070633

54. Koso S, Furikado I, Shimao A, Miyazawa T, Kunimori K, Tomishige K (2009) Chem Commun 2035

55. Bhaumik A, Tatsumi T (1999) J Catal 182:349

56. Bhaumik A, Tatsumi T (1998) Chem Commun 463

57. Hamamoto H, Suzuki Y, Takahashi H, Ikegami S (2007) Adv Synth Catal 349:2685

58. Marton D, Slaviero P, Tagliavini G (1989) Tetrahedron 45:7099 